\title{
Hydrological response to land use and land cover changes in a sub-watershed of West Liaohe River Basin, China
}

\author{
XiaoLi YANG ${ }^{1}$, LiLiang REN ${ }^{1 *}$, Yi LIU ${ }^{1}$, DongLai JIAO $^{2}$, ShanHu JIANG ${ }^{1}$ \\ ${ }^{1}$ State Key Laboratory of Hydrology-Water Resources and Hydraulic Engineering, Hohai University, Nanjing 210098, China; \\ ${ }^{2}$ College of Geographic and Biologic Information, Nanjing University of Posts and Telecommunications, Nanjing 210046, China
}

\begin{abstract}
In recent years, the streamflow of the Laohahe Basin in China showed a dramatic decrease during the rainy season as a result of climate change and/or human activities. The objective of this work was to document significant streamflow changes caused by land use and land cover (LULC) changes and to quantify the impacts of the observed changes in Laohahe Basin. In the study area, the observed streamflow has been influenced by LULC changes, dams, and irrigation from rivers, industry, livestock and human consumption. Most importantly, the growth of population and gross domestic product (GDP) accompanied by the growth in industrial and agricultural activities, which led to LULC changes with increased residential land and cropland and decreased grassland since 2000s. Statistical methods and Variable Infiltration Capacity (VIC) hydrological model were used to estimate the effects of climate change and LULC changes on streamflow and evaportranspiration (ET). First, the streamflow data of the study area were divided into three sub-periods according to the Pettitt test. The hydrological process was then simulated by VIC model from 1964 to 2009. Furthermore, we compared the simulated results based on land use scenarios in 1989, 1999 and 2007, respectively for exploring the effect of LULC changes on the spatio-temporal distribution of streamflow and ET in the Laohahe Basin. The results suggest that, accompanied with climate change, the LULC changes and human water consumption appeared to be the most likely factors contributing to the significant reduction in streamflow in the Laohahe Basin by 64\% from1999 to 2009.
\end{abstract}

Keywords: hydrological response; land use and land cover changes; streamflow; evapotranspiration; semi-arid region

Citation: XiaoLi YANG, LiLiang REN, Yi LIU, DongLai JIAO, ShanHu JIANG. 2014. Hydrological response to land use and land cover changes in a sub-watershed of West Liaohe River Basin, China. Journal of Arid Land, 6(6): 678-689. doi: 10.1007/s40333-014-0026-4

Land use and land cover (LULC) changes contribute to changes in the energy, hydrological and biogeochemical cycles of the Earth's system, thereby leading to climate and ecosystem change, which affects the ability of biological systems to support human needs (Vitousek et al., 1997). Some researches indicated that deforestation can increase flood risk, because deforestation causes canopy interception storage, transpiration, and infiltration capacity to decrease (Bradshaw et al., 2007; Laurance, 2007). Naef et al. (2002) recognized that the effects of LULC changes on river flows were more evident in arid climates, where the low river flows were more sensitive to LULC changes. Brown et al. (2005) found that changes in LULC affected not only annual mean streamflow but also the flow regime. Zhang and Schilling (2006) concluded that increased streamflow in the Mississippi River was mainly due to an increase in baseflow as a result of LULC changes.

Laohahe Basin, a typical farming-pastoral zone in China, has shown an increasing tendency of drought, with streamflow decreased dramatically or frequent discontinuous flows even in the rainy seasons. The main LULC types in Laohahe Basin include woodland, cropland and grassland, which have been significantly modified and converted over the last 50 years (Yang et al., 2012). The studies for this region showed that the streamflow would decrease by about $25 \%$ during the

*Corresponding author: LiLiang REN (E-mail: rll@hhu.edu.cn) 
$21^{\text {st }}$ century compared to the late $20^{\text {th }}$ century (1990-2000) (Liu et al., 2009; Jiang et al., 2012). Jiang et al. (2012) found that human activities led to a $90 \%$ of decrease in streamflow in this region. Decreased streamflow can cause a serious impact on the environment, the river and estuary ecosystems, and social and economic systems. The objective of this research is to quantitatively assess the impacts of LULC changes on streamflow and evapotranspiration by using statistical methods and the VIC land surface model. This study will deepen our understanding of the hydrological response to global change in semi-arid regions, which is crucial for effective planning, management and sustainable development of water resources in such regions.

\section{Study area and method}

\subsection{Study area}

The study area is selected at Laohahe Basin, which is one of main tributaries of the West Liaohe River with an area of approximately $18,968 \mathrm{~km}^{2}$. This basin is located at the junction of Hebei, Liaoning provinces and Inner Mongolia autonomous region, in the Northeast of China $\left(41^{\circ}-43^{\circ} 20^{\prime} \mathrm{N}, 117^{\circ} 05^{\prime}-119^{\circ} 50^{\prime} \mathrm{E}\right)$. The land use types of the basin are dominated by grassland, woodland and cropland. There are 52 rain gauges, 4 meteorological stations and 1 streamflow station (Fig. 1). The basin comprises a variety of landforms, ranging from grassland plains to hills en- compassing valleys, and uplands with elevation ranging from approximately $427 \mathrm{~m}$ asl near the Xinglongpo hydrological station to $2,000 \mathrm{~m}$ asl on the eastern border of the watershed. The study area belongs to a typical semi-arid climate, with an average annual precipitation of $451 \mathrm{~mm}$, an annual average temperature of $7.5^{\circ} \mathrm{C}$ and runoff of $27.2 \mathrm{~mm}$ during the past 46 years, respectively. In this area, grassland and cropland are two dominant land use types and woodland is the third predominant land use type. Agriculture within this basin developed quickly in the 1980s, and livestock numbers increased greatly in 1989. The agricultural crop species including maize, helianthus, murphy and wheat are mainly located in the south-east and north-west middle regions of the whole basin. The main soil textures are sandy clay loam, sandy loam and clay loam according to the United States Department of Agriculture soil classification (USDA, 1993).

\subsection{Data collection}

The meteorological data from 1964 to 2009 at Chifeng, Weichang, Jianping, and Wengniuteqi meteorological stations were collected from China Meteorological Administration. The data included daily records of mean, maximum and minimum temperatures, sunshine hours, wind speed and air water vapor pressure. The daily precipitation, streamflow and pan evaporation (Pan-ET) data were from 52 rain gauges distributed in the whole study area, which were provided by

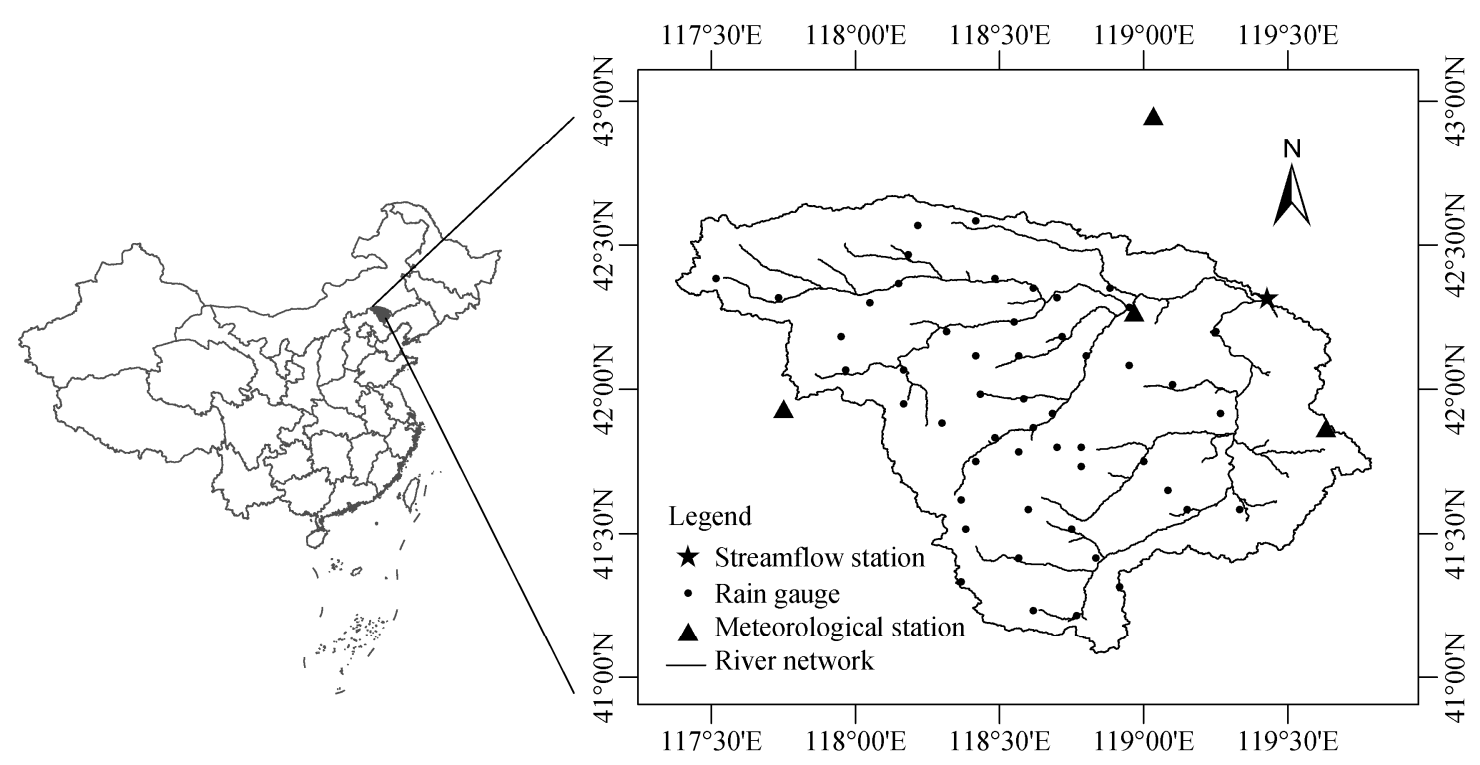

Fig. 1 The location of rain gauges, meteorological stations and streamflow station of the Laohahe Basin 
the Water Resources Department of the Inner Mongolia autonomous region. All meteorological data were interpolated over the whole basin by using the inverse distance square method (Ashraf et al., 1997). The Shuttle Radar Topography Mission (SRTM) 3-second digital elevation model (DEM) data (http:// lpdaac.usgs.gov/gtopo30/hydro/index.html) were used to represent the topography of the study area. The LULC data were from three Landsat images (Landsat5 TM images (1989), Landsat7 ETM+ images (1999); Landsat 5 TM images (2007)), which were classified by the Support Vector Machine (SVM) method (Cortes and Vapnik, 1995). The growing season, changing in different ages and basin regions was taken into account in the classifying process and the field survey data in 2008 were used for evaluating the accuracy of the classification. The LULC in 1989 was used for calibration and validation of the VIC model. The LULC maps in 1999 and 2007 were used to simulate the impact of LULC changes on streamflow and evaportranspiration. We derived the soil texture types from the Food and Agriculture Organization data set, which were transferred to USDA soil types basing on the percent of clay, sand and silt in the triangular soil classification system (FAO/UNESCO, 2003). The vegetation types were obtained from the University of Maryland's 1-km global land cover products (Hansen et al., 2000).

\subsection{The trend and change-point analysis}

Analysis of trends in long-term hydrological data is important for detecting and understanding changes in the rainfall-streamflow process (Kliment, 2011). In this study, the Mann-Kendall's test (Mann, 1945; Kendall, 1975) was used to quantitatively analyze the change trend and significance level for annual precipitation, streamflow, temperature, Pan-ET and AET. The precipitation-streamflow double cumulative curve (DCC) (Huo et al., 2008) and Pettitt test (Pettitt, 1979) were used to detect the change points of the streamflow for the hydrological period of 1964-2009 in Laohahe Basin. The DCC is a scatter plot of the cumulative annual precipitation and streamflow of each year in the study area, providing a visual representation of the consistency of the precipitation and streamflow data (Matouškovă, 2009).

The Pettitt test is one of the most important statistical indicators in analyzing the hydrological response to climate variability and human activities (such as LULC changes, withdrawal and dams). This method can detect an unknown change point by considering a time series as two samples represented by $X_{1}, X_{2}, \ldots$, $X_{t}$ and $X_{t+1}, \ldots, X_{T}$, which come from the same time series data. The $t$ is considered as a break if value of $T$ was maximized. The test statistic $U_{t, T}$ is given by Pettitt indices, which can be calculated from the following formula (Kiely et al., 1998):

$$
U_{t, T}=\sum_{i=1}^{t} \sum_{j=t+1}^{T} \operatorname{sgn}\left(x_{t}-x_{j}\right) .
$$

The most significant change-point is found where the value $\left|U_{t, T}\right|$ is max. Where $\operatorname{sgn}(\theta)$ can be calculated as:

$$
\operatorname{sgn}(\theta)=\left\{\begin{array}{ccc}
1 & & \theta>0 \\
0 & \text { if } & \theta=0 \\
-1 & & \theta<0
\end{array}\right.
$$

The series of probabilities of change-points for each year is given by the Eq. 3 (Kiely et al., 1998):

$$
P \cong 1-\exp \left[\frac{-6\left(U_{t, U}\right)^{2}}{N^{3}+N^{2}}\right] .
$$

The Mann-Kendall's test, a nonparametric method, is frequently used to detect the significance of monotonic trends in hydrometeorological time series, which does not need any assumption about the distribution of the experimental data (Yue et al., 2002; Alan et al., 2003). The standard normal statistic $(Z)$ indicates the trend strength in Mann-Kendall's test method (Douglas et al., 2000). A positive value of $Z$ represents an upward trend, while a negative value indicates a downward trend. The null hypothesis of no trend is rejected if $|Z|>1.96$ at the $5 \%$ significance level and is also rejected if $|Z|>2.33$ at the $1 \%$ significance level. More detail description about this method references the former literatures (Douglas et al., 2000; Yue et al., 2002; Alan et al., 2003).

\subsection{The variable infiltration capacity model}

The Variable Infiltration Capacity (VIC) model is a semi-distributed grid-based hydrological model, which parameterizes the dominant hydro-meteorological processes taking place at the land surface-atmosphere interface (Liang et al., 1994; Liang et al., 1996), and solves the coupled water and energy balances. The sub-grid heterogeneity is included through a statistical parameterization for infiltration 
capacity and a division of each grid cell into tiles on the basis of land use types and elevation zones (Hurkmans et al., 2009). The VIC hydrological model has been successfully applied in many river basins in China during recent years (Yuan et al., 2004; Wang et al., 2010; Yong et al., 2013). In the VIC model, climate data for this study, including daily precipitation, maximum and minimum temperatures and daily average wind speed were interpolated to each $0.0625^{\circ} \times 0.0625^{\circ}$ (spatial resolution in the study area) model grid cell. The VIC model mainly contains two kinds of parameters, i.e. soil parameters and vegetation parameters. The soil parameters were obtained from the LDAS Parameters web site (http://ldas. gsfc.nasa.gov/nldas/NLDASsoils.php) and the vegetation parameters were obtained from http://www.hydro. washington.edu/Lettenmaier/Models/VIC/Documentation/VegParam.shtml. In these parameters, there are seven most sensitive parameters need to be calibrated during calibration. They are soil depths $\left(d_{1}, d_{2}\right.$ and $\left.d_{3}\right)$, $D_{\mathrm{s}}, B, D_{\text {smax }}$ and $W_{\mathrm{s}}$. The $d_{1}, d_{2}$ and $d_{3}$ are three soil layer depths in the study area. The $D_{\mathrm{s}}$ is the fraction of $D_{\text {smax }}$ where non-linear (rapidly increasing) baseflow begins. $B$ defines the shape of the variable infiltration capacity curve. The $D_{\text {smax }}(\mathrm{mm} / \mathrm{d})$ is the maximum baseflow that can occur at the lowest soil layer. $W_{\mathrm{s}}$ is the fraction of the maximum soil moisture (of the lowest soil layer), where non-linear baseflow occurs.

\subsection{Hydrologic model calibration and validation}

In this study, the routing model was adopted to produce the model-simulated streamflow at the Xinlongpo hydrological station. The year of 1964 was used for VIC model spin-up, 1965-1971 was the model calibration period, and 1972-1976 was the verification period. The optimized parameter values and statistic indices for evaluating the model calibration were summarized in Table 1 . We adopted BIAS, the Nash-Sutcliffe Coefficient of Efficiency (NSCE), and the coefficient of correlation $(r)$, three of the commonly used statistical criteria, to evaluate the hydrologic model performance. The correlation coefficient (r), NSCE and BIAS at a monthly scale were $0.92,0.85$ and 5\% during the calibration period of 1965-1971, and were $0.8,0.82$ and $2 \%$ during the validation period of 1972-1976, respectively. Figure 2 shows the variable characteristics of precipitation, observed streamflow and simulated results in the calibration period (Fig. 2a) and verification period (Fig. 2b). The model calibration demonstrated that VIC was capable of capturing key features of the observed hydrograph (e.g. peak magnitude, recession and base flow) quite well at monthly time series when forced by the rain gauge precipitation.

\section{Results and discussion}

\subsection{LULC changes in Laohahe Basin}

The main LULC types in Laohahe Basin include grassland, cropland, woodland, residential land, barren land and water body. The cropland, grassland and woodland are the predominant land use types in this semi-arid region. From 1989 to 2007, there have been dramatic changes in LULC in this basin, such as increases in residential land, barren land and woodland and decrease in grassland. The area of woodland increased and the increasing ratio between the two periods was about 39.6:1.0. The area of grassland decreased by $24.9 \%$, while the barren land and residential land increased sharply by about $266.2 \%$ and $142.5 \%$, respectively. From 1989 to 1999 , the urban

Table 1 Seven critical parameters calibrated in the VIC-3L model

\begin{tabular}{|c|c|c|c|}
\hline Parameter & Description & Range & Value \\
\hline$B$ & Variable infiltration curve parameter & $0-0.4$ & 0.30 \\
\hline$d_{1}$ & Thickness of top soil moisture layer & $0.05-0.1$ & 0.07 \\
\hline$d_{2}$ & Thickness of third soil moisture layer & $0-2$ & 0.57 \\
\hline$d_{3}$ & Thickness of second soil moisture layer & $0-2$ & 2.00 \\
\hline$D_{\mathrm{s}}$ & Fraction of $D_{\text {smax }}$ where non-linear baseflow begins & $0-1$ & 0.01 \\
\hline$W_{\mathrm{s}}$ & Maximum velocity of baseflow & $0-3$ & 9.00 \\
\hline$D_{\text {smax }}$ & Fraction of maximum soil moisture where non-linear baseflow occurs & $0-1$ & 0.98 \\
\hline
\end{tabular}




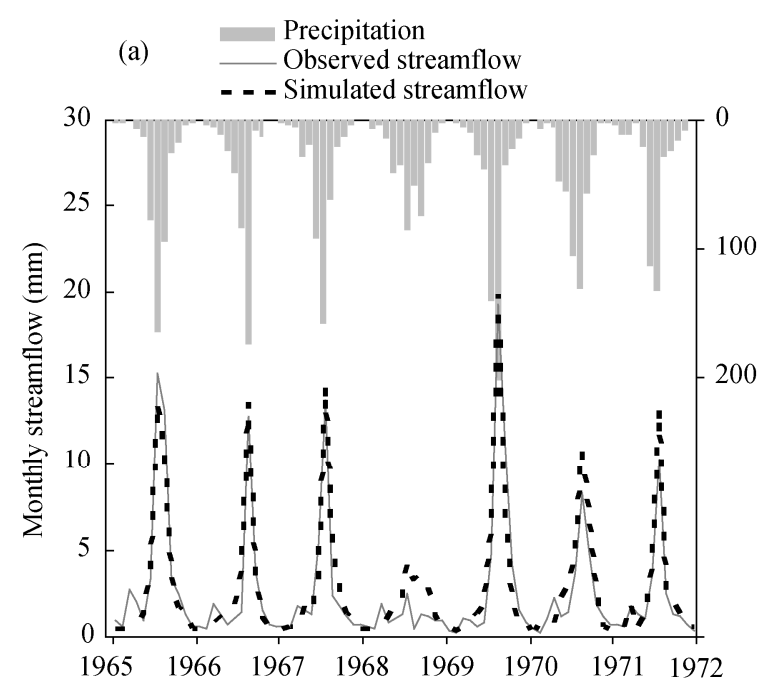

(b)

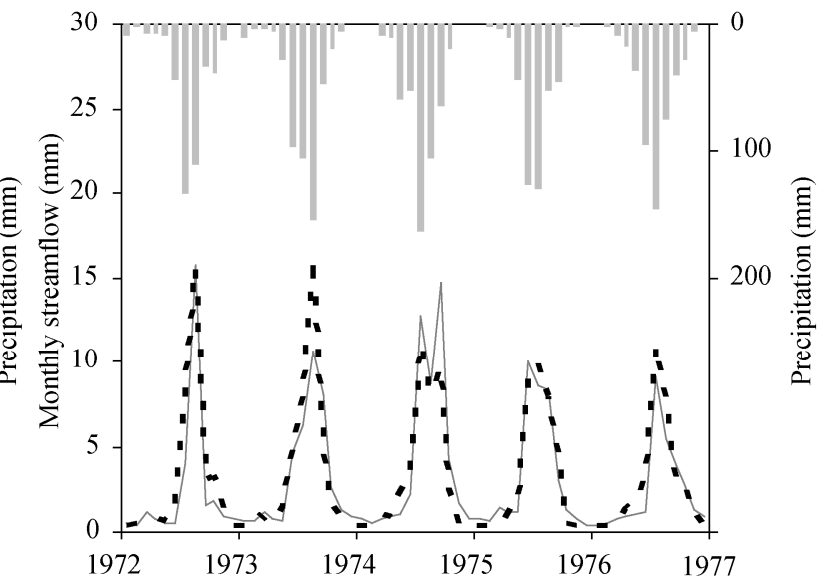

Fig. 2 Observed and simulated monthly streamflows for (a) calibration period (1965-1971) and (b) validation period (1972-1976)

area increased by about $220.0 \%$, meanwhile the woodland and barren land also increased obviously by $13.0 \%$ and $60.3 \%$, respectively. During the period of 1999-2007, the area of grassland decreased by $21.6 \%$ while it was only $4.2 \%$ during the period of 1989-1999. The cropland decreased by $9.9 \%$ in the first period but increased by $12.1 \%$ in the second period. Meanwhile, the barren land had a significant increase of $51.3 \%$ over the first period (Fig. 3). The LULC in Laohahe Basin suggested that agriculture development rate has accelerated in the $21^{\text {st }}$ century, accompanied with fast urbanization process and serious desertification. The general rule in LULC changes is as follows: grasslands were mainly converted to woodland, barren land and residential land. Land degradation, especially the development of cultivated land, was the main reason for regional environmental deterioration.

\subsection{Effects of LULC changes on streamflow of Laohahe Basin}

The spatial and temporal distribution of precipitation was uneven in Laohahe Basin. The most significant precipitation (about $88 \%$ of an annual precipitation) occurs in the summer season, while the precipitation in spring and winter was very scarce. In the time series of mean annual streamflow and precipitation in Laohahe Basin during 1964-2009, there was an obvious inhomogeneity by Pettitt test with two change-points for the streamflow series (1979 with a probability of $97 \%$ and 1998 with a probability of
99\%) and for the precipitation series (1979 with a probability of $45 \%$ and 1998 with a probability of 90\%) (Fig. 4a). The annual precipitation-streamflow double cumulative curve demonstrated a positive correlation between precipitation and streamflow before 1979 and after 1999 except the period from 1980 to 1998 (Fig. 4b).

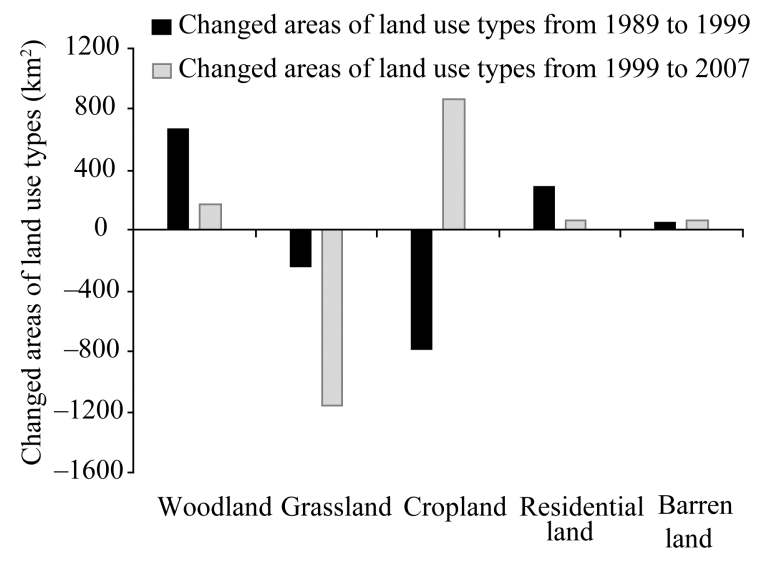

Fig. 3 Changed areas of predominant land use types (woodland, grassland, cropland, residential land and barren land) from 1989 to 2007 in the study area

According to the Pettitt test and precipitationstreamflow double cumulative curve (DCC) analysis, there should be two change-points (1979 and 1998) of streamflow in the long-term means of hydrological variables. Therefore, we compared the flow duration curve of three sub-periods in Fig. 4c. It shows that the maximum streamflow in the period of 1999-2009 was lower than that of the former two periods by $32.5 \%$. To clearly exhibit the changes of hydrologic parame- 

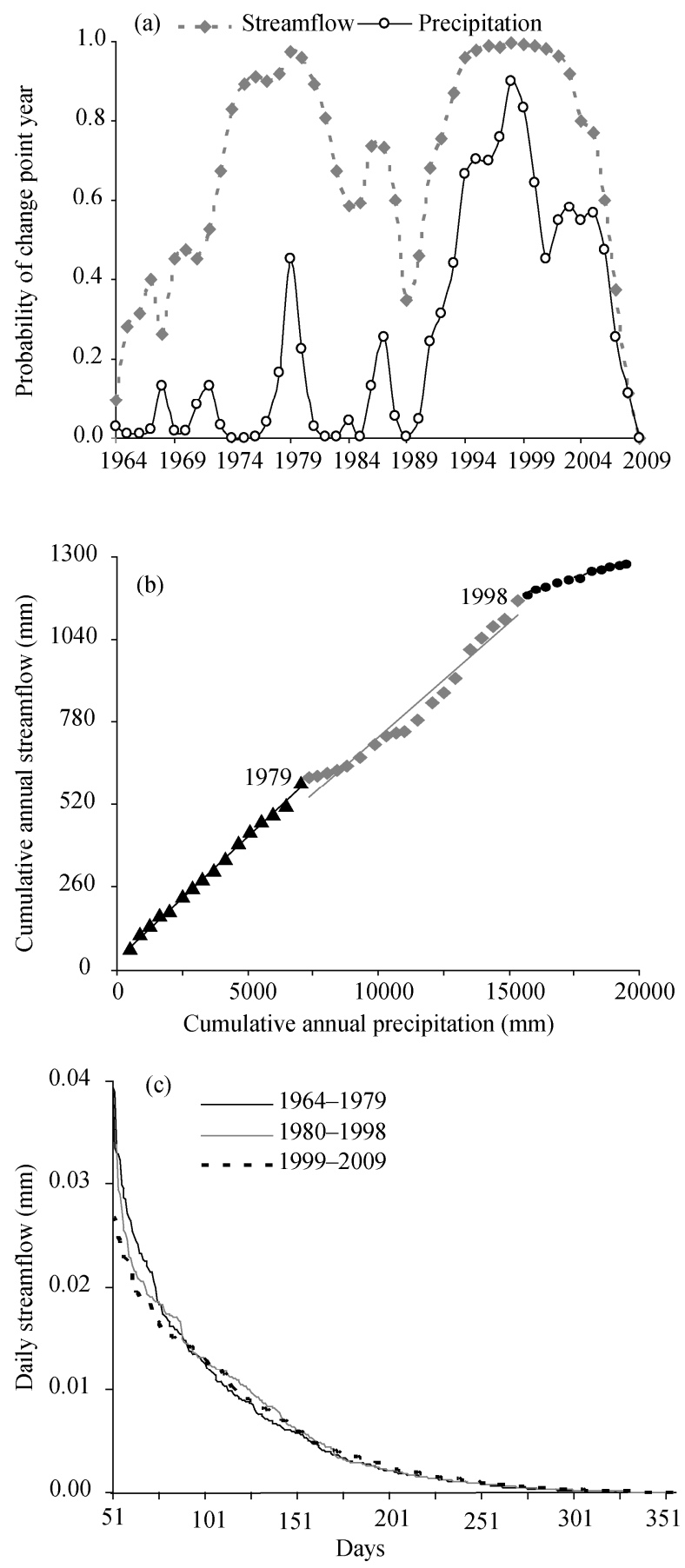

Fig. 4 The trend and change-point analysis by (a) Pettitt test of annual mean precipitation and streamflow, (b) DCC of annual mean precipitation-streamflow double cumulative curve, and (c) daily flow duration curve

ters in Laohahe Basin, we presented the tendencies of long-term means of daily precipitation, streamflow, evaportranspiration (ET) and runoff coefficient in Table 2. In this statistics processing, the long-term ET is calculated by the difference between daily precipita- tion and observed streamflow. The precipitation almost stands stable while the streamflow shows a slight increase, and the runoff coefficient has a light increase from 0.083 to 0.102 from the first period (1964-1979) to the second period (1980-1998). However, in the last period (1999-2009), precipitation and streamflow both decreased by $0.165 \mathrm{~mm} / \mathrm{d}$ (about $13.8 \%$ ) and $0.094 \mathrm{~mm} / \mathrm{d}$ (about $77.0 \%$ ), respectively. In the third period, the runoff coefficient had a dramatic decrease from 0.102 (in the second period) to 0.027 (about $73.5 \%$ ) and the ET shows a slightly decrease by 0.071 $\mathrm{mm} / \mathrm{d}$ over the same period. Decreasing runoff coefficient (percentage of precipitation that appears as runoff) implies that the same rainfall produces less streamflow now than before. It clearly pointed out that the changes in the rainfall-streamflow relationships were disproportionate after 1998, which suggested that factors such as irrigation, withdrawing and increased water consumption could impose an impact on the streamflow change of the Laohahe River are necessary for further analyses.

\subsection{Effects of LULC changes on basin streamflow}

Compared with the direct effect of precipitation, land use change affects hydrologic processes primarily through two mechanisms: its link with the evapotranspiration regime and the degree and type of ground cover, which has an enormous impact on the initiation of surface streamflow. The VIC hydrologic model was used for quantitatively estimating the effect of land use and climate changes on streamflow and evaportranspiration. To further detect the deviations between precipitation and streamflow, we plotted the inter-annual variations in the hydrologic cycle, including precipitation, temperature, observed and simulated streamflow in Fig. 5. The hydrology period was divided into five sub-periods as D1 for dry year before 1970, D2 for wet year during 1970s, D3 for dry year during the 1980s, D4 for wet year during the 1990s, and D5 for dry year after 2000 (Yong et al., 2013) for analyzing their long term annual characteristics in the study area. The average precipitations in the periods of D2 and D4 were about 455 and $473 \mathrm{~mm} / \mathrm{a}$, respectively, which were higher than that of D3 (with the value of $396 \mathrm{~mm} / \mathrm{a}$ ) and D5 (with the value of 392 $\mathrm{mm} / \mathrm{a}$ ). The temperature change was relatively stable with an upward tendency $(Z=4.51, P<0.01)$, which 
increased by $0.34^{\circ} \mathrm{C} / \mathrm{a}$ from 1964 to 2009 . The biggest change was contributed by streamflow in D5, which was the lowest for the whole hydrological period, while the precipitation and temperature of this period were similar with that of D3. The differences between observed streamflow and simulated streamflow were higher in dry years than in wet years, e.g. differences of about 18 and $19 \mathrm{~mm}$ in the periods of D3 and D5 were observed while that of D2 and D4 were about 3 $\mathrm{mm}$. This can be attributed to more water withdrawal for agriculture irrigation, stock raising, industry, etc. during dry periods, which contributes to the decrease of streamflow.

Table 2 Long-term means of hydrological variables in Laohahe Basin

\begin{tabular}{ccccc}
\hline Period & $\mathrm{P}(\mathrm{mm} / \mathrm{d})$ & $\mathrm{Q}(\mathrm{mm} / \mathrm{d})$ & $\mathrm{ET}(\mathrm{mm} / \mathrm{d})$ & $\mathrm{C}(\mathrm{Q} / \mathrm{P})$ \\
\hline $1964-1979$ & 1.204 & 0.100 & 1.104 & 0.083 \\
$1980-1998$ & 1.200 & 0.122 & 1.078 & 0.102 \\
$1999-2009$ & 1.035 & 0.028 & 1.007 & 0.027 \\
\hline
\end{tabular}

Note: $\mathrm{P}$ is precipitation (average of the hydrological station records in whole basin), Q is streamflow (from the hydrological station records in Xinglongpo station), ET is evapotranspiration (from the equation of $\mathrm{ET}=\mathrm{P}-\mathrm{Q})$ and $\mathrm{C}$ is the runoff coefficient $(\mathrm{C}=\mathrm{Q} / \mathrm{P})$.

For understanding the effect of LULC changes on monthly streamflow in the study area, differences of streamflow among the three land use scenes were compared in Fig. 6, where the streamflow was separately generated using the land use input of 1989 , 1999 or 2007 with the same meteorological data from 1964 to 2009 for VIC model. The black dash line was

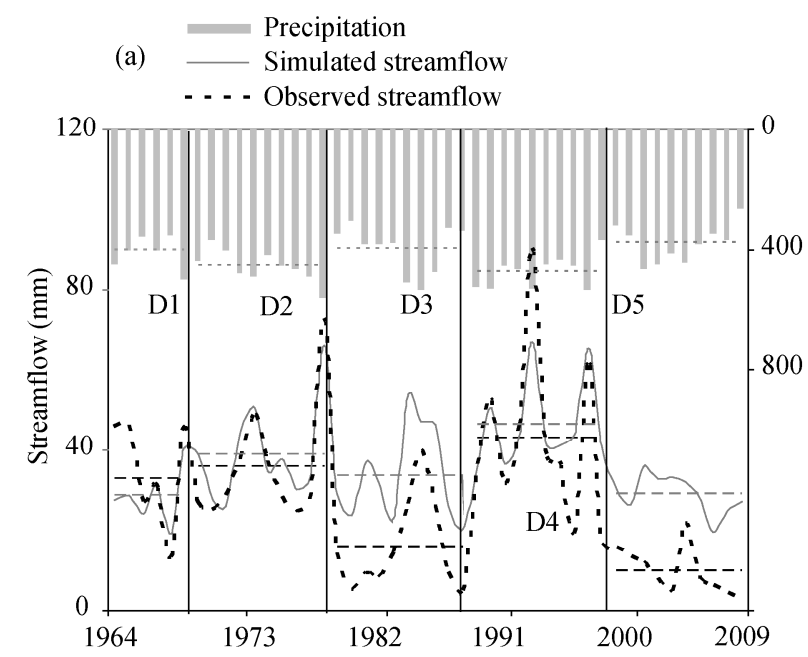

the difference between streamflow from land use in 1999 and 2007 (the value of streamflow from land use of 1999 minus that of 2007) and the gray line was the difference value of streamflow from land use of 1989 minus that of 1999. It showed that the streamflow difference between land use in 1999 and 2007 was bigger than that between 1989 and 1999 with an average value of about $0.33 \mathrm{~mm}$. The highest value of this different was located in the period of 1990 to 1999 with higher precipitation. The decreased annual streamflow caused by three LULC scenarios was presented in Fig. 7. The black curve represented the decreased streamflow from land use scenario in 1999 to that of 2007, while the gray curve represented the decreased streamflow from land use in 1989 to that of 1999. It shows that the streamflow decreased from 1989 to 1999 with increases in forest and residential area and decrease in grassland (Fig. 3), and the streamflow decreased from 1999 to 2007 with the dramatic decrease in grassland and significant increase in cropland. It implied that LULC change had a direct effect on the changing streamflow in this region.

The population and gross domestic product (GDP) showed an increasing tendency from 1964 to 2009 in the basin. Specifically, the GDP increased dramatically in the $21^{\text {st }}$ century while the population was relatively stable. There were two big dams built in 2000 (Table 3). The records obtained from the "Hydrological Year Book" published by the Hydrological Bureau of the Ministry of Water Resources showed that the withdrawals of the river water from Laohahe Basin

Fig. 5 Variations in inter-annual total precipitation, mean observed streamflow, mean modeled streamflow (a), and mean temperature (b) over the period of 1964-2009 and sub periods (D1 for 1964-1969, D2 for 1970-1979, D3 for 1980-1989, D4 for 1990-1999, and D5 for 2000-2009) at Xinglongpo station in Laohahe Basin. The dashed line is the average value of each variation in every sub period. 
Table 3 Building and reinforcement information of large reservoirs within the Laohahe Basin

\begin{tabular}{llccc}
\hline Name of reservoir & Location of reservoir & Type of dam project & Duration & Storage capacity $\left(10^{8} \mathrm{~m}^{3}\right)$ \\
\hline Erdao Hezi & $\left(42.30^{\circ} \mathrm{N}, 119.00^{\circ} \mathrm{E}\right)$ & Newly built & $2000-2001$ & 0.8 \\
Da Hushi & $\left(41.42^{\circ} \mathrm{N}, 118.68^{\circ} \mathrm{E}\right)$ & Maintenance and reinforcement & $1999-2000$ & 1.2 \\
\hline
\end{tabular}

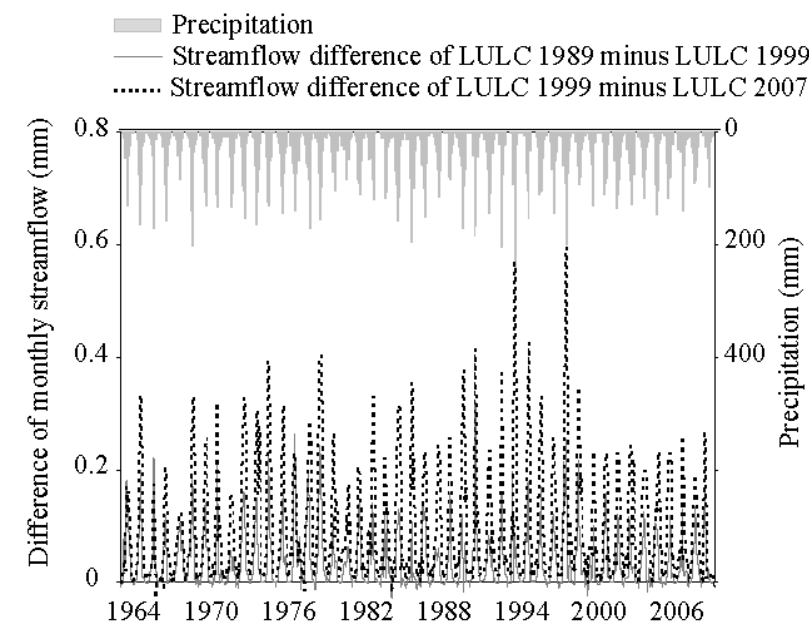

Fig. 6 Simulated monthly streamflow variations using VIC model with same meteorological data from different LULC data (LULC1989, LULC1999 and LULC2007) in Laohahe Basin

were about $1.9 \times 10^{9}$ and $1.4 \times 10^{9} \mathrm{~m}^{3}$ in 2002 and 2006 , respectively, while the observed streamflow left in the river in the same years were $2.4 \times 10^{9}$ and $1.4 \times 10^{9} \mathrm{~m}^{3}$. A point worth reiterating is that the decrease in precipitation and increased human activities are the main factors contributing to the dramatic decrease in streamflow in the basin.

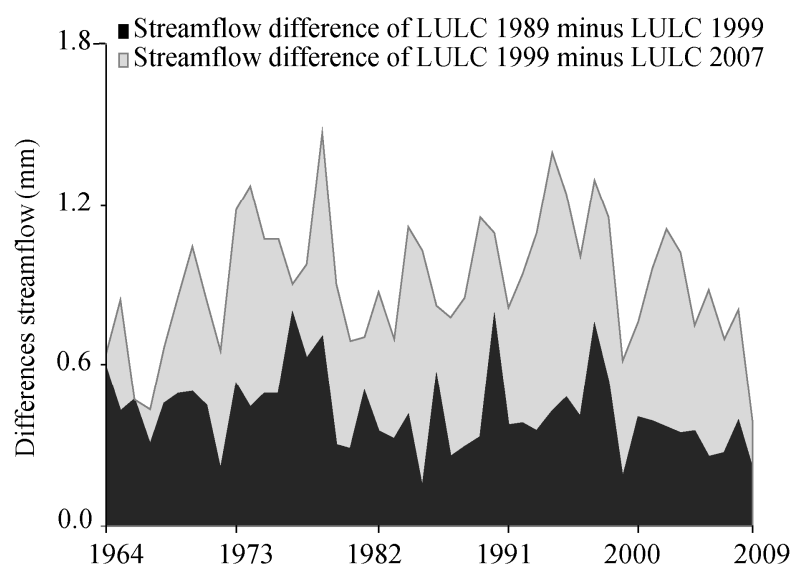

Fig. 7 The decreased annual streamflow caused by land use changes from 1989 to 1999 and from 1999 to 2007 in Laohahe Basin

In addition, to investigate the sensitivity of streamflow to LULC changes, we devised some extreme hypothetical scenarios, where all land use types throughout the basin were replaced by each of the three predominating land use types (cropland, woodland and grassland). The time series of streamflow were simulated by the VIC model for all land use change scenarios by using original atmospheric forcing data set and parameters calculated for calibration period, which covered the period of 1964 to 2009 (Fig. 8 ). It clearly showed that the averages annual streamflow for woodland, grassland and cropland were about 29,42 and $35 \mathrm{~mm} / \mathrm{a}$, respectively. And the streamflow of forest land was lower than that of grassland and cropland by about 13 and $6 \mathrm{~mm} / \mathrm{a}$, respectively. Within the hydrological cycle, rainfall interception by vegetation is an important hydrological process. According to previous experiments for estimating the interception characteristics of different vegetation types, data for mature forest from Spittlehouse (1998) and Giles (1983) suggested that potential interception was about 25\%-35\%. In particular, the most notable difference occurred in 1979 and 1998, which showed similar trend with the Pettitt test result for change-point detection. This implied that the decrease in magnitude of surface flow was directly associated with the changes in LULC types.

\subsection{Modeled effects of LULC changes on evapo- transpiration}

Evapotranspiration (ET) is a key variable in the terrestrial water cycle that provides the link between the land surface and the atmosphere, which is potentially the largest component of the land water budget and is therefore central to quantifying and managing water resources (Sheffield et al., 2010). A number of studies (Milly, 1994; Zhang et al., 2001; Yang et al., 2013) have shown that, in spite of the complexity in the soil-vegetation-atmosphere system, the most important factors controlling annual mean evapotranspiration appear to be annual rainfall and land use types. The difference in rainfall interception between forests and short grass has important implications for basin water balance because most of the intercepted rainfall is evaporated directly into the atmosphere (Zhang et al., 1999). To assess the effect of LULC changes on 
the evapotranspiration, we analyzed the spatiotemporal characteristics of actual evapotranspiration (AET) in the basin. The time series variations of annual precipitation, pan evaporation (from observed station record) and actual evapotranspiration (AET) simulated by the VIC model were presented in Fig. 9. It was obvious that the Pan-ET of the entire Laohahe Basin decreased dramatically in the last 46 year. And the $Z$ value of Pan-ET in Mann-Kendall's test was -4.29 , which was at $1 \%$ significance level. Meanwhile, the AET had a slight downward trend $(Z=0.72)$, similar to the temporal tendency of precipitation $(Z=-1)$.

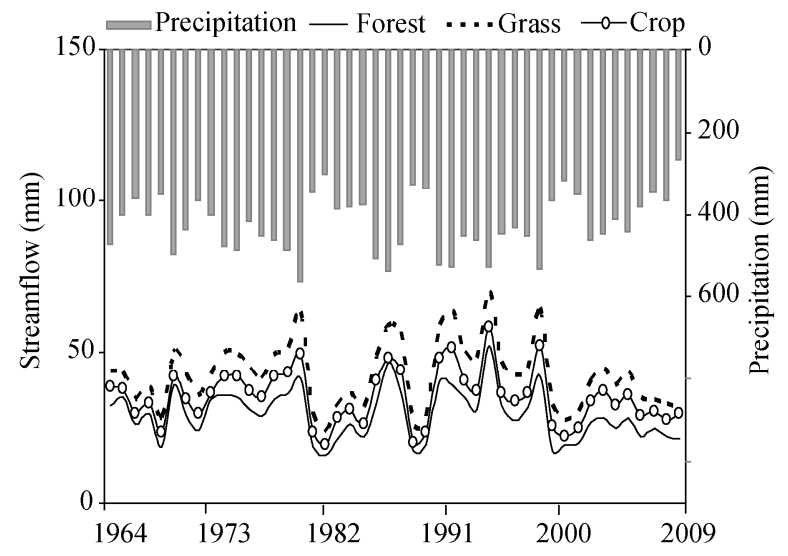

Fig. 8 Inter-annual variation of simulated annual mean streamflow from three designed vegetation types (forest, crop, and grass) by VIC model

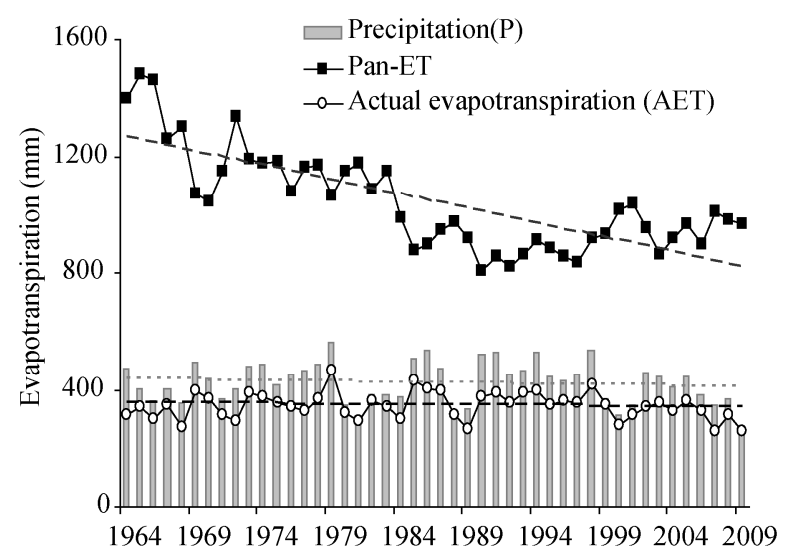

Fig. 9 Time series variations of annual precipitation, pan evaporation, and simulated actual evapotranspiration from 1964 to 2009 for the entire Laohahe Basin

According to the two change-points (1979 and 1998) from the Pettitt test and precipitation-streamflow double cumulative curve (DCC) analysis, we compared the values of AET and Pan-ET between the three periods. The pan evaporation has a dramatic decrease from the first period (1964-1979) to the second period
(1980-1998) by $277 \mathrm{~mm}$ in the multi-year average of each period. And there was a slight increase of $1.1 \%$ from 1999 to 2009 in comparison to the period of 1980-1998. The AET kept relatively stable during the period of 1980-1998 and significantly decreased by about $12 \%$ after 1999 , which was consistent with the situations reported globally by other researches (Brutsaert and Parlange, 1998; Roderick et al., 2009; Shen et al., 2009). Because of contributions of the dry environment and temperature increasing with global warming, the Pan-ET showed a decrease trend, which predicated the decrease of the AET in semi-arid regions. Figure 10 shows the variations in runoff coefficient $(\mathrm{Q} / \mathrm{P})$ and ratio of actual evapotranspiration and precipitation for entire Laohahe Basin from 1964 to 2009. The runoff coefficient significantly dropped from 0.08 in the $1960 \mathrm{~s}$ to 0.02 in the $2000 \mathrm{~s}(Z=-3.18$, $P<0.01)$. The ratio of actual evapotranspiration and precipitation is a fairly common approach in ET studies (Brutsaert, 1982), with the values varying between 0 and 1 . The ratio would approach 1 for low values of precipitation or high values of temperature. From 1964 to 2009, the ratio of actual evapotranspiration and precipitation showed an evident upward tendency. It demonstrated that the change of AET was dominated by the change in precipitation and temperature, which also coincides with the conclusions of Yang et al. (2006). This change verifies that climate warming has a direct effect on the characteristics of evapotranspiration.

LULC changes will alter surface vegetation types,

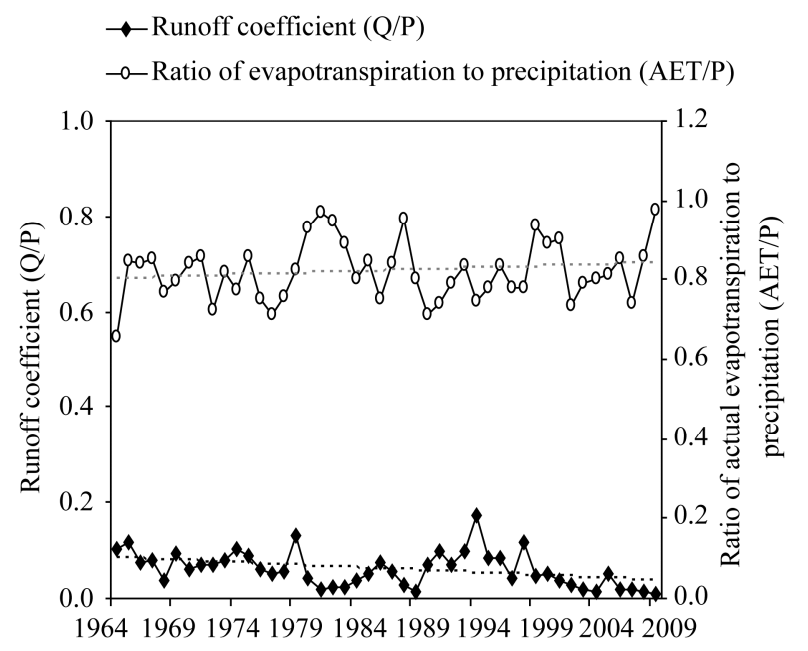

Fig. 10 Time series variations of the ratio of actual evapotranspiration to precipitation (AET/P) and runoff coefficient $(Q / P)$ for the entire Laohahe Basin during the period of 1964-2009 
which directly affects the evapotranspiration process parameters that contribute to the spatial and temporal uniform characteristics of ET. Total actual evapotranspiration (AET) is the sum of canopy evaporation, transpiration from each vegetation tile and bare soil evaporation from the bare soil tile, weighted by the coverage fraction for each surface cover class. The changes in vegetation cover can alter surface roughness and Leaf Area Index (LAI), influencing the surface energy balance and evapotranspiration (Pielke and Avissar, 1990; Greeneet al., 1999; Mao and Cherkauer, 2009). Therefore, based on the simulated results of the VIC model, we compared the annual actual evapotranspiration for three designed predominant vegetation types in the study area, which was presented in Fig. 11. It shows that the AETs changed with the change of precipitation. The averages of annual AET of forest, grass and crop are 365.1, 324 and $345.9 \mathrm{~mm}$, respectively. Forest has the highest AET compared to the other two vegetation types. Cropland has higher AET than that of grassland due to higher density, deeper root system and bigger vegetation cover, which contribute to the transpiration. In particular, the forest is generally very closely coupled to the atmosphere and its evapotranspiration rate is dominated by turbulent transport, which increases catchment evapotranspiration compared to grassland. The differences of annual AET among the three vegetation types are bigger in wet years than in dry years. The mean difference of average annual AET between forest and cropland (grassland) is $19 \mathrm{~mm} / \mathrm{a}(41 \mathrm{~mm} / \mathrm{a})$. Overall, changes in the predominant vegetation types determine the AET behavior of the study area, which will cause a decrease in mean annual streamflow and an increase in the variability of annual streamflow (Peel et al., 2002).

\section{Conclusions}

In this study, we investigated the effects of LULC changes on streamflow and evapotranspiration in Laohahe Basin. The Pettitt test and DCC analysis were used to detect the change point in the annual streamflow time series of 1964-2009. Basing on the results of statistical analysis, we applied the VIC model to simulate the streamflow and evapotranspiration in the study area. Three LULC scenarios classified from Landsat images in 1989, 1999 and 2007 were used as the input land use data for VIC model. In addition, to investigate the sensitivity of streamflow and evapotranspiration to LULC changes, we devised some extreme hypothetical scenarios, where all land use types throughout the basin were replaced by each of three predominating land use types (cropland, woodland and grassland). Streamflow and evapotranspiration were then simulated by the VIC model for all hypothetical land use scenarios by using original atmospheric forcing data and calibrated parameters, which covered the period of 1964 to 2009.

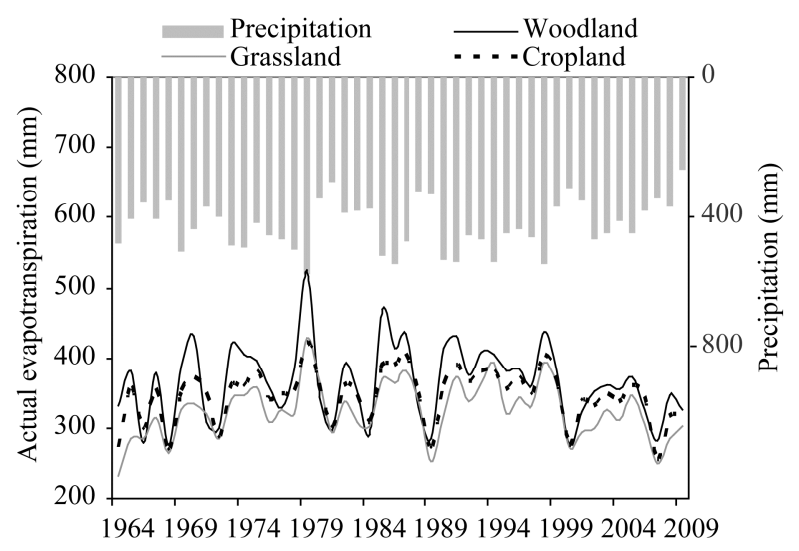

Fig. 11 Annual AET using VIC model for three predominant designed vegetation types (forest, crop and grass) from 1964 to 2009 in study area

The LULC changes were dramatic during the past 46 years in Laohahe Basin. The statistical analysis showed that the streamflow and ET characteristics of Laohahe Basin were modified dramatically from 1964 to 2009. Since 1999, the streamflow, ET and runoff coefficient values showed a decreasing trend. During the period of 1999-2009, the streamflow decreased by about $64 \%$ compared to the period of 1964-1998 while the precipitation just slightly changed. The results of VIC model simulation showed that the streamflow from forest land was lower than that from grassland and cropland by about 13 and $6 \mathrm{~mm} / \mathrm{a}$, respectively. Meanwhile, the woodland increased catchment evapotranspiration compared to grassland and cropland. The insights gained in this study would provide more evidence and useful reference for water resources planning and management in such semi-arid regions.

\section{Acknowledgements}

This work was financed by the National Natural Science Foundation of China (41201031), the Special Basic Research 
Fund for Methodology in Hydrology of Ministry of Sciences and Technology, China (2011IM011000), the Innovative Research Team Project of Basic Research Funds for National University at State Key Laboratory of Hydrology-Water Resources and Hydraulic Engineering (2009585412), the 111 Project of Ministry of Education and State Administration of Foreign Experts Affairs, China (B08048), and the National Key Technology R\&D Program by Ministry of Sciences and Technology, China (2013BAC10B02). We thank the three anonymous reviewers for their constructive comments.

\section{References}

Alan D Z, Justin S, Edwin P M, et al. 2003. Detection of intensification in global- and continental-scale hydrological cycles: temporal scale of evaluation. Journal of Climate, 16: 535-547.

Ashraf M, Loftis J C, Hubbard K G. 1997. Application of geostatistics to evaluate partial weather station networks. Agricultural and Forest Meteorology, 84(3-4): 255-271.

Bradshaw C J A, Sodhi N S, Peh K S H, et al. 2007. Global evidence that deforestation amplifies flood risk and severity in the developing world. Global Change Biology, 13: 1-17. FAO/UNESCO. 2003. Digital Soil Map of the World and Derived Soil Properties, CD-ROM, Version 3.6. Information Division, FAO, 00100 Rome, Italy.

Brown A G, Hatton J, O'Brien C E, et al. 2005. Vegetation, landscape and human activity in midland ireland: mire and lake records from the lough kinale-derragh lough area, central ireland. Vegetation History and Archaeobotany, 14(2): 81-98.

Brutsaert W. 1982. Evaporation into the Atmosphere: Theory, History, and applications. Netherlands: wh Brutsaert. D. Reidel Publishing Company, 229.

Brutsaert W, Parlange M. 1998. Hydrologic cycle explains the evaporation paradox. Nature, 396(6706): 30-30.

Cortes C, Vapnik V. 1995. Support-vector networks. Machine Learning, 20(3): 273-297.

Douglas E M, Vogel R M, Kroll C N. 2000. Trends in floods and low flows in the united states: impact of spatial correlation. Journal of Hydrology, 240: 90-105.

Giles D G. 1983. Soil water regimes on a forested watershed. MSc Thesis. Vancouver, BC: University of British Columbia.

Hansen M, DeFries R, Townshend J R, et al. 2000. Global land cover classification at $1 \mathrm{~km}$ spatial resolution using a classification tree approach. International Journal of Remote Sensing, 21(6-7): 1331-1364.

Huo Z L, Feng S Y, Kang S Z, et al. 2008. Effect of climate changes and water-related human activities on annual stream flows of the shiyang river basin in arid north-west China. Hydrological Processes, 22: 3155-3167.

Hurkmans R T W L, Terink W, Uijlenhoet R, et al. 2009. Effects of land use changes on streamflow generation in the Rhine basin. Water Resources Research, 45: 1-15.

Jiang S H, Ren L L, Yong B, et al. 2012. Analyzing the effects of climate variability and human activities on runoff from the laohahe basin in northern China. Hydrology Research, 43(1-2): 3-13.

Kendall M G. 1975. Rank Correlation Methods. London: Charles Griffin and Company Limited.
Kiely G, Albertson J, Parlange M. 1998. Recent trends in diurnal variation of precipitation at Valentia on the west coast of Ireland. Journal of Hydrology, 207(3): 270-279.

Kliment Z, Matoušková M, Ledvinka O, et al. 2011. Trend analysis of rainfall-runoff regimes in selected headwater areas of the Czech Republic. Journal of Hydrology and Hydromechanics, 59(1): 36-50.

Laurance W F. 2007. Forests and floods. Nature, 449: 409-410.

Liang X, Lettenmaier D P, Wood E F, et al. 1994. A simple hydrologically based model of land surface water and energy fluxes for general circulation models. Journal of Geophysical Research-Atmospheres, 99: $14415-14428$.

Liang X, Wood E F, Lettenmaier D P. 1996. Surface soil moisture parameterization of the vic-21 model: evaluation and modification. Global and Planet Change, 13(1): 195-206.

Liu X F, Ren L L, Yuan F, et al. 2009. Quantifying the effect of land use and land cover changes on green water and blue water in northern part of China. Hydrology and Earth System Sciences, 13(6): 735-747.

Mann H B, 1945. Nonparametric tests against trend. Econometrica, 13(3): 245-259.

Matouškovă Z K M. 2009. Runoff changes in the Sumava Mountains (black forest) and the foothill regions: extent of influence by human impact and climate change. Water Resources Management, 23: 1813-1834

Mao D, Cherkauer K A. 2009. Impacts of land-use change on hydrologic responses in the Great Lakes region. Journal of Hydrology, 374: $71-82$.

Milly P C D. 1994. Climate, soil water storage, and the average annual water balance. Water Resources Research, 30(7): 2143-2156.

Naef F, Scherrer S, Weiler M. 2002. A process based assessment of the potential to reduce flood runoff by land use change. Journal of Hydrology, 267(1-2): 74-79.

Peel M C, McMahon T A, Finlayson B L, et al. 2002. Implications of the relationship between catchment vegetation type and the variability of annual runoff. Hydrological Processes, 16(15): 2995-3002.

Pettitt A N. 1979. Testing for bivariate normality using the empirical distribution function. Communications in Statistics-Theory and Methods, 8(7): 699-712.

Roderick M L, Hobbins M T, Farquhar G D. 2009. Pan evaporation trends and the terrestrial water balance. I. principles and observations. Geography Compass, 3(2): 746-760.

Sheffield J, Wood E F, Munoz-Arriola F. 2010. Long-term regional estimates of evapotranspiration for Mexico based on downscaled ISCCP data. Journal of Hydrometeorology, 11: 253-275.

Shen Y, Liu C, Liu M, et al. 2009. Change in pan evaporation over the past 50 years in the arid region of China. Hydrological Processes, 24(2): 225-231.

Spittlehouse D L. 1998. Rainfall interception in young and mature conifer forests in British Columbia. In Proceedings $23^{\text {rd }}$. Conference on Agricultural and Forest Meteorology, 2-6 November 1998, Albuquerque, N.M. Boston: American Meteorological Society, 171-174.

US Department of Agriculture, Soil Survey Staff. 1993. National Soil Survey Handbook. Washington: USDA, Soil Conservation Service, US Government Printing Office. 
Vitousek P M, Mooney H A, Lubchenko J, et al. 1997. Human domination of earth's ecosystems. Science, 277(5325): 494-499.

Wang J, Hong Y, Gourley J, et al. 2010. Quantitative assessment of climate change and human impacts on long-term hydrologic response: a case study in a sub-basin of the yellow river, China. International Journal of Climatology, 30(14): 2130-2137.

Yang D W, Sun F B, Liu Z T, et al. 2006. Interpreting the complementary relationship in non-humid environments based on the Budyko and Penman hypotheses. Geophysical Research Letters, 33(18): 1-5. L18402.

Yang X L, Ren L L, Singh V P, et al. 2012. Impacts of land use and land cover changes on evapotranspiration and runoff at Shalamulun river watershed, China. Hydrology Research, 43(1-2): 23-37.

Yang X L, Ren L L, Jiao D L, et al. 2013. Estimation of daily actual evapotranspiration from $\mathrm{ETM}^{+}$and MODIS data over the head water of West Liao River Basin in semi-arid region, China. Journal of Hydrologic Engineering, 18(11): 1530-1538.

Yong B, Ren L L, Hong Y, et al. 2013. Spatial-temporal changes of water resources in a typical semi-arid basin of north China over the past 50 years and assessment of possible natural and socioeconomic causes. Journal of Hydrometeorology, 14: 1009-1034.

Yuan F, Xie Z H, Liu Q, et al. 2004. An application of the vic-31 land surface model and remote sensing data in simulating streamflow for the Hanjiang river basin. Canadian Journal of Remote Sensing, 30(5): 680-690.

Yue S, Pilon P, Cavadias G. 2002. Power of the mann-kendall and Spearman's rho tests for detecting monotonic trends in hydrological series. Journal of Hydrology, 259: 254-271.

Zhang L, Dawes W R, Walker G R. 1999. Predicting the effect of vegetation changes on catchment average water balance. In: Cooperation Research Center for Catchment Hydrology. Technical Report 99/12. Canberra, Monash University, Victoria, Australia.

Zhang L, Dawes W R, Walker G R. 2001. Response of mean annual evapotranspiration to vegetation changes at catchment scale. Water Resources Research, 37(3): 701-708.

Zhang Y K, Schilling K. 2006. Increasing streamflow and baseflow in Mississippi River since the 1940s: effect of land use change. Journal of Hydrology, 324(1): 412-422. 